\title{
Factors influencing electroporation-mediated gene transfer to Stylosanthes guianensis (Aubl.) Sw. protoplasts
}

\author{
V.M. Quecini, C.A. de Oliveira, A.C. Alves, M.L.C. Vieira \\ Laboratório de Biologia Celular e Molecular de Plantas, Departamento de Genética - ESALQ/USP, \\ Piracicaba, SP, Brazil.
}

\begin{abstract}
In order to develop a high-efficiency and reproducible transformation protocol for Stylosanthes guianensis we assessed the biological and physical parameters affecting plant electroporation protoplasts. Energy input, as combinations of electric field strengths discharged by different capacitors, electroporation buffer and DNA form were evaluated. Transformation efficiency was assayed in vivo as transient reporter gene expression, using the GFP-coding gene mgfp5 driven by a CaMV 35 S constitutive promoter. Energy input and electric field strength had a critical influence on transgene expression with higher transformation levels being achieved with $250 \mathrm{~V} . \mathrm{cm}^{-1}$ discharged by 900 and $1000 \mu \mathrm{F}$ capacitors. Linear plasmid DNA, the absence of chloride and the presence of calcium ions also increased transient gene expression, albeit not significantly.
\end{abstract}

Key words: direct gene transfer, plant transformation, forage legume, Stylosanthes guianensis.

Received: February 4, 2000; accepted: March 14, 2002.

\section{Introduction}

The genus Stylosanthes (Fabaceae) comprises approximately 50 predominantly herbaceous species and subspecies native to tropical and subtropical regions of Asia, Africa and the Americas, principally South America. In the last two decades considerable progress has been made towards the identification of promising species for use as pasture in Brazil and Colombia (van der Stappen et al., 1998; Vieira et al., 1997; Liu et al. 1996).

Due to their vigorous growth habit, deep rooting ability and resistance to poor and infertile soils Stylosanthes species, associated with a wide range of grasses, are currently being used as protein banks, green manure and, principally, as forage crops (Lovato and Martins, 1997; Partridge, 1996). Although its characteristics favor the use of Stylosanthes as animal feed, the quantity and, especially, the quality of its proteins serve as constraints on its use as the sole feed source for extensive and intensive cattle feeding.

Stylosanthes is considered one of the least recalcitrant legume genus in respect to regeneration (Cônsoli et al., 1996; Dornelas et al., 1992; Dornelas et al., 1991; Meijer and Szabados, 1990; Vieira et al., 1990) and in vitro cell and tissue culture of Stylosanthes is well established, making molecular breeding strategies feasible (Portykus, 1990). The

Send correspondence to M.L.C. Vieira. Departamento de Genética, ESALQ, USP, C.P. 83, 13400-970 Piracicaba, SP, Brazil. E-mail: mlcvieir@carpa.ciagri.usp.br. main drawback to long-term in vitro Stylosanthes culture is the induction of genetic and epigenetic changes (Cônsoli et al., 1996; Valarini et al., 1997).

To our knowledge, genetic transformation of Stylosanthes has only been mediated by the use of Agrobacterium tumefaciens and Agrobacterium rhizogenes (Manners, 1987; Manners, 1988; Manners and Way, 1989) and transgenic plants have only recently been obtained (Sarria et al., 1994). These methods, depending on complex plant-pathogen interactions, result in low transformation efficiency due to legume-bacteria incompatibility (Ankenbauer and Nester, 1993; Cônsoli et al., 1995; Mauro et al., 1995; Yang, 1993) or selective marker negative effect on shoot regeneration (Hoffmann, 1998; Colby and Meredith, 1990).

Direct genetic transformation relies on physical and chemical forces to introduce foreign nucleic acid into a host genome, these methods having the advantage that they can be universally employed because no biological interaction is involved. Electroporation and microparticle bombardment are the principal systems for direct gene delivery to legumes (Aragão et al., 1999; Quorin et al., 1997; Potrykus, 1991).

Biological membranes are composed of phospholipids, amphipatic molecules that have a hydrophilic head group attached to a hydrophobic tail, and are able to be polarized when submitted to electric fields. Electric pulses raise the transmembrane potential, promoting transient pore formation due to the increased dipole moment of the 
hydrophilic lipid heads (Kinosita and Tsong, 1977; Neumann et al., 1982), allowing charged macromolecules to migrate through the pores and eventually reach the nucleus where they can promote genetic transformation.

Protoplast electroporation allows the introduction of foreign DNA into a great variety of cells, and these cells can be regenerated into transformed plants depending on the effectiveness of the shoot regeneration protocol. Under these conditions, transformation efficiency is higher than that obtained using high efficiency systems $e$.g. biolistics (Quecini, 1999).

In this article we describe a highly effective protocol for the transformation of Stylosanthes guianensis (Aubl.) Sw. (cv. Mineirão) protoplasts by electroporation. Electric field strength, energy input, DNA form and electroporation buffer were assessed in order to optimize transformation rates. Reporter gene expression and transgene PCR amplification was observed in regenerated plants.

\section{Material and Methods}

\section{Plant material and tissue culture methods}

Seeds of Stylosanthes guianensis (Aubl.) Sw. (cv. Mineirão) were provided by Embrapa/Cerrados (Brasília, Brasil). After surface sterilization (30 s in $70 \%$ ethanol followed by $15 \mathrm{~min}$ in $2 \%$ calcium hypochloride and abundant rinsing in autoclaved water) seeds were germinated in vitro in half-strength Murashige and Skoog (MS) medium (Murashige and Skoog, 1962) without growth regulators but containing $1.5 \%(\mathrm{w} / \mathrm{v})$ sucrose and solidified with $0.18 \%$ (w/v) Phytagel (Sigma). Fully expanded cotyledons excised from 7-8 day old seedlings were used for protoplast isolation as described by Vieira et al. (1990).

Freshly isolated protoplasts were re-suspended in electroporation buffer containing $10 \mu \mathrm{g}$ of plasmid DNA per $800 \mu \mathrm{L}$ (the volume of the electroporation cuvette) to give $2 \times 10^{6}$ protoplasts $\mathrm{mL}^{-1}$ and the mixture gently agitated on ice for $30 \mathrm{~min}$, after which the mixture was transferred to $0.4 \mathrm{~cm}$ electrode gap cuvettes (BioRad). The electroporation buffers investigated were designate buffer I (Fromm et al., 1987), buffer II (Tada et al., 1990) and buffer III (Walbot, 1993).

After electroporation, the protoplasts were carefully removed from the cuvettes and cultivated as described by Vieira et al. (1990) in liquid media (Kao, 1977 modified by Gilmour et al., 1989) at a density of $1 \times 10^{6}$ protoplasts $\mathrm{mL}^{-1}$. Cultures were maintained under a $16 \mathrm{~h}$ light regime $\left(75 \pm 3 \mu \mathrm{E} \mathrm{m}^{-2} \mathrm{~s}^{-1}\right)$ at $25 \pm 2.4^{\circ} \mathrm{C}$. Shoots ( $2-4 \mathrm{~cm}$ long) were base excised from the callus and induced to root in MS medium containing $1 \%(\mathrm{w} / \mathrm{v})$ sucrose, a regenerated plantlet being shown in Figure 1E. Individual shoots were

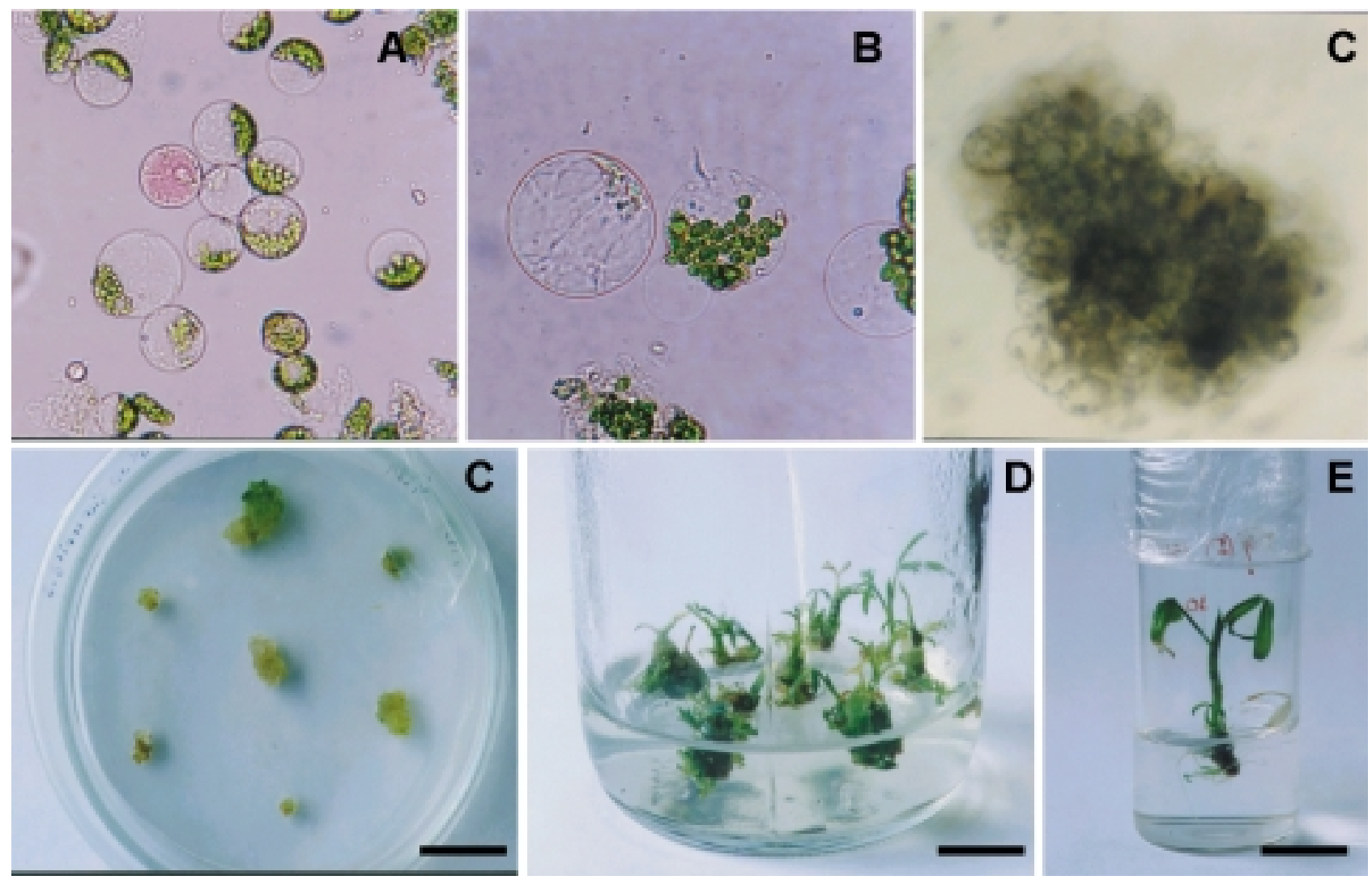

Figure 1 - Plant regeneration from protoplasts of Stylosanthes guianensis. (A) isolated protoplasts $400 \mathrm{x},(\mathbf{B})$ in vitro dividing cell $400 \mathrm{x},(\mathbf{C})$ microcalli $200 \mathrm{x},(\mathbf{D})$ organogenic calli $(\mathrm{bar}=1.33 \mathrm{~cm}),(\mathbf{E})$ shoot initiation from calli $(\mathrm{bar}=1.33 \mathrm{~cm}),(\mathbf{F})$ rooting plantlet $(\mathrm{bar}=0.67 \mathrm{~cm})$. 
histochemically assayed (Jefferson et al., 1987) for $\beta$-glucuronidase (GUS) expression. A specific polymerase chain reaction (PCR) transgene amplification method was also used.

\section{Plasmid characteristics}

The transient expression assay vector pCambia 1304 (CAMBIA GPO Box 3200, Canberra ACT 2601, Australia) carries a selective marker gene (hpt II) conferring hygromycin resistance and a fusion between the reporter genes coding for GUS (uidA) and a green fluorescent protein (GFP) ( $m g f p 5)$, both driven by a $35 \mathrm{~S}$ promoter from cauliflower mosaic virus (CaMV) as shown in Figure 2.

Plasmid DNA was independently transformed into $E$. coli JM 109 cells (Dower et al., 1988) or DH5a (Hanahan, 1983) and purified by the cesium chloride method (Sambrook et al., 1989). Supercoiled plasmid DNA was directly employed in transformation experiments or linearized by digestion with Eco RI (GIBCO BRL). Concentrations of plasmid DNA were spectrophotometrically determined at $260 \mathrm{~nm}$ and confirmed by Tris-borate EDTA (TBE)-gel electrophoresis in $0.8 \%$ agarose (Sambrook et al., 1989).

\section{Electroporation conditions}

Exponential decay pulses were applied by a commercial device (Bio Rad Gene Pulser II with Capacitance Extender) to $0.4 \mathrm{~cm}$ electrode gap cuvettes $(800 \mu \mathrm{L})$ containing $1.6 \times 10^{6}$ protoplasts and $10 \mu \mathrm{g}$ of plasmid DNA.

Electric discharges from 400, 800, 900 and $1000 \mu \mathrm{F}$ capacitors at electric field strengths of 125, 200, 250 and $300 \mathrm{~V} . \mathrm{cm}^{-1}$ were used, providing the following energy inputs to the system: $500,1280,2000,2880 \mathrm{~mJ}$ for the $400 \mu \mathrm{F}$ capacitor; $1000,2560,4000$ and $5760 \mathrm{~mJ}$ for the $800 \mu \mathrm{F}$ capacitor; $1125,2880,4500$ and $6480 \mathrm{~mJ}$ for the $900 \mu \mathrm{F}$ capacitor; $1250,3200,5000$ and $7200 \mathrm{~mJ}$ for the $1000 \mu \mathrm{F}$ capacitor. Sample resistance was $20 \Omega$ (buffers I and III) and $50 \Omega$ (buffer II) as measured by the Gene Pulser. The length of the pulse (time) was established by the internal settings of the apparatus, and can be expressed as the pulse decay constant $(\tau=\mathrm{RC})$.

\section{Analysis of GFP expression}

Electroporated protoplasts were re-suspended in culture medium (Kao, 1977 modified by Gilmour et al., 1989) to give $1.0 \times 10^{6}$ protoplasts $\mathrm{mL}^{-1}$ and kept in the dark for $24 \mathrm{~h}$ at $4{ }^{\circ} \mathrm{C}$. Non-electroporated protoplasts in $800 \mu \mathrm{L}$ of electroporation buffer with $10 \mu \mathrm{g}$ of plasmid DNA were ice-incubated for $45 \mathrm{~min}$. As a measure of transformation efficiency, the number of transgene-expressing and nonexpressing protoplasts were scored using fluorescence microscopy at $\lambda=395 \mathrm{~nm}$.

\section{Polymerase chain reaction (PCR) analysis}

Genomic DNA was isolated from plantlets derived from electroporated or non-electroporated protoplasts as described by Edwards et al. (1991).

Each $25 \mu \mathrm{L}$ of reaction mixture contained $20 \mathrm{ng}$ of genomic DNA, $10 \mathrm{mM}$ TRIS- $\mathrm{HCl}(\mathrm{pH} 8.4), 50 \mathrm{mM} \mathrm{KCl}$, $2.0 \mathrm{mM} \mathrm{MgCl}_{2}, 160 \mu \mathrm{M}$ of each dNTP, $1.0 \mathrm{U}$ of Taq polymerase (GIBCO BRL) and $200 \mathrm{nM}$ of each uidA specific primer (gus $1=$ CCT GTA GAA ACC CCA CAA CG and gus 2 = TGC AGC GCT ACC TAA GGC CG) (Figure 2), which provide an amplification product of $795 \mathrm{bp}$.

The mixture was overlaid with sterile mineral oil. Denaturation was performed at $95^{\circ} \mathrm{C}$ for $2 \mathrm{~min}$, followed by 25 amplification cycles in a Thermus (Perkin Elmer) thermal cycler $\left(1 \mathrm{~min}\right.$ at $94{ }^{\circ} \mathrm{C}, 1 \mathrm{~min}$ at $45^{\circ} \mathrm{C}$ and $1.5 \mathrm{~min}$ at $72^{\circ} \mathrm{C}$ ) with a final extension of $7 \mathrm{~min}$ at $72^{\circ} \mathrm{C}$. DNA amplification products migrated on $1.4 \%(\mathrm{w} / \mathrm{v})$ agarose TBE gels, were stained with ethidium bromide $\left(10 \mu \mathrm{g} \mathrm{mL}^{-1}\right)$ and detected with ultraviolet light.

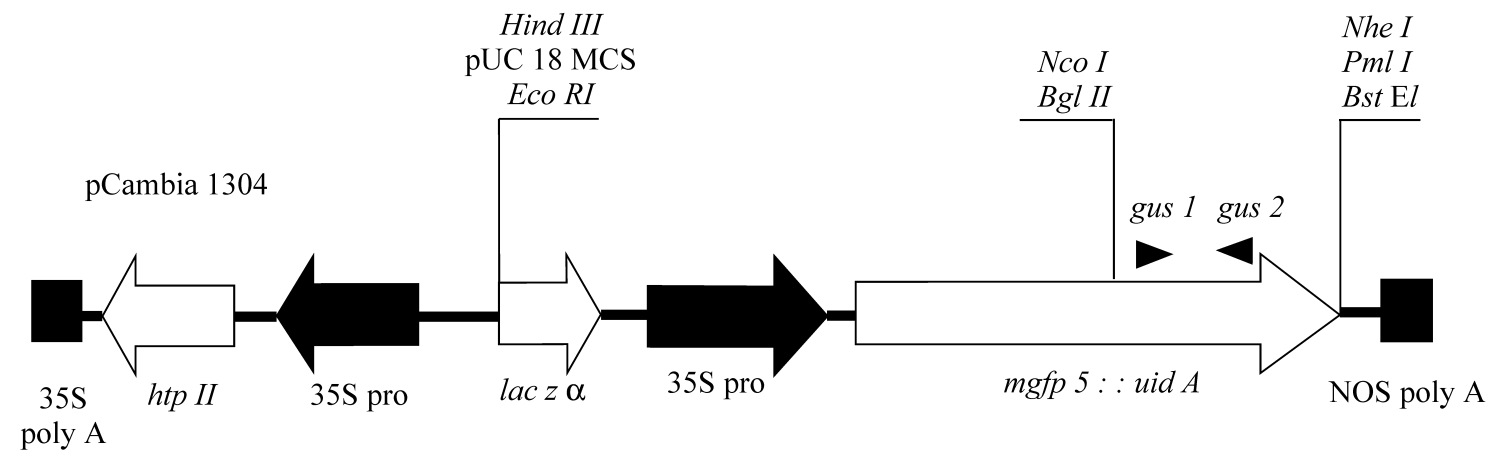

Figure 2 - Transformation vector pCambia 1304 expression cassette. PCR primers are indicated by (gus 1 ) and (gus2). Arrows indicate cloning direction. Regulatory sequences (polyadenilation signals $=$ polyA and promoters $=$ pro) are shown as black segments. $\mathrm{MCS}=$ multicloning site, $\mathrm{NOS}=$ nopaline synthase, lacz $\alpha=\alpha$ subunit of bacterial lactase. 


\section{Results and Discussion}

\section{Optimizing the field strength for the delivery of} foreign DNA to $S$. guianensis protoplasts

We used the transient expression of a gene coding for a green fluorescent protein (GFP) (Chalfie et al., 1994) for the in vivo evaluation of transformation efficiency. The frequency of transformants increased up to $3000 \mathrm{~mJ}$ of energy input (Figure 3A). While capacitors with a higher charge accumulation capacity $(900$ and $1000 \mu \mathrm{F})$ gave higher transformation frequencies ( $50 \%$ ) when used in the range of 2000 to $4000 \mathrm{~mJ}$, capacitors of lower charge accumulation ( 400 and $800 \mu \mathrm{F})$ led to the death of approximately $70 \%$ of the protoplasts (Figure 3A). Maximum transient gene expression has been reported under electric field strengths causing more than $50 \%$ reduction in protoplast viability (Fromm et al., 1985; Hauptmann et al., 1987; Oard et al., 1989).

Electric field (EF) strength is related to the electrode gap (d) and the discharged voltage (V) according to the equation $\mathrm{EF}=\mathrm{V} \cdot \mathrm{d}^{-1}$, while the induced energy discharge $(\varepsilon)$ is dependent on the capacitor and the applied voltage $(\mathrm{V})$ according to $\varepsilon=\mathrm{CV}^{2}$. Figure $3 \mathrm{~B}$ shows that $\mathrm{EF}$ values of $250 \mathrm{~V} . \mathrm{cm}^{-1}$ discharged by 900 and $1000 \mu \mathrm{F}$ capacitors resulted in high transformation rates in electroporated protoplasts. Less intense electric fields were unable to promote reporter gene expression in more than $20 \%$ of electroporated protoplasts, while stronger electric fields induced irreparable plasma membrane damage, causing extensive cellular death and virtually no transformation.

Transient membrane pores are caused by an increase in the dipole moment of hydrophilic phospholipid heads, which move in the same direction as the applied electric field and provoke highly localized dielectric breakages in membrane structure (Kinosita and Tsong, 1977; Neumann et al., 1982; Neumann et al., 1996). Irreversible pores which lead to cellular death are caused by longer pulses and stronger electric fields (Langridge et al., 1987; Shillito et al., 1985), and we found that this occurred with energy inputs of more than $5000 \mathrm{~mJ}$ (Figure 3A) or electric fields stronger than $300 \mathrm{~V} . \mathrm{cm}^{-1}$ (Figure 3B). Even so, protoplast electroporation has been reported as a mean of increasing cell division (Rech et al., 1987), plant regeneration (Chand et al., 1988; Ochatt et al., 1988) and DNA synthesis (Rech et al., 1988). However, in our experiments, plant regeneration was slower from electroporated than from non-electroporated protoplasts (Table I).

We observed specific transgene amplification in shoots regenerated from electroporated protoplasts (Figure $4)$.

\section{Effect of the electroporation buffer on DNA introduction}

Figure 5 shows that transient expression frequency of the GFP was significantly $(p<0.01)$ higher with buffer II and lowest with buffer I, while an intermediary frequency was obtained with buffer III. Non-viable and damaged protoplasts were rarely seen after electroporation in buffer II, which gave almost $100 \%$ expression of GFP (Figure $6 \mathrm{~A})$. However, we found that the frequency of stable

Table I - Comparison of plant regeneration efficiency from electroporated and non-electroporated $S$. guianensis protoplasts. See text for electroporation conditions.

\begin{tabular}{lcc}
\hline & Non-electroporated & Electroporated \\
\hline $\begin{array}{l}\text { Protoplasts per cotyledon pair } \\
\left(\mathrm{x} 10^{5}\right)\end{array}$ & $4.57 \pm 0.73$ & $5.67 \pm 0.85$ \\
Protoplast viability $^{1}(\%)$ & $76.00 \pm 2.46$ & $21.00 \pm 7.09$ \\
Division frequency (\%) $(\% .50 \pm 1.66$ & $0.70 \pm 3.33$ \\
Plating efficiency $^{2}(\%)$ & $1.90 \pm 0.14$ & $0.02 \pm 6.67$ \\
Regeneration frequency $^{3}(\%)$ & $85.00 \pm 3.41$ & $72.00 \pm 7.29$ \\
\hline
\end{tabular}

*Mean values of 4 independent experiments \pm standard errors. $1=24 \mathrm{~h}$ after electroporation.

$2=\mathrm{N}$. of colonies after 45 days culture divided by the N. of plated protoplasts.

$3=\mathrm{N}$. of calli with shoots after 90 days of culture divided by the N. of plated calli.
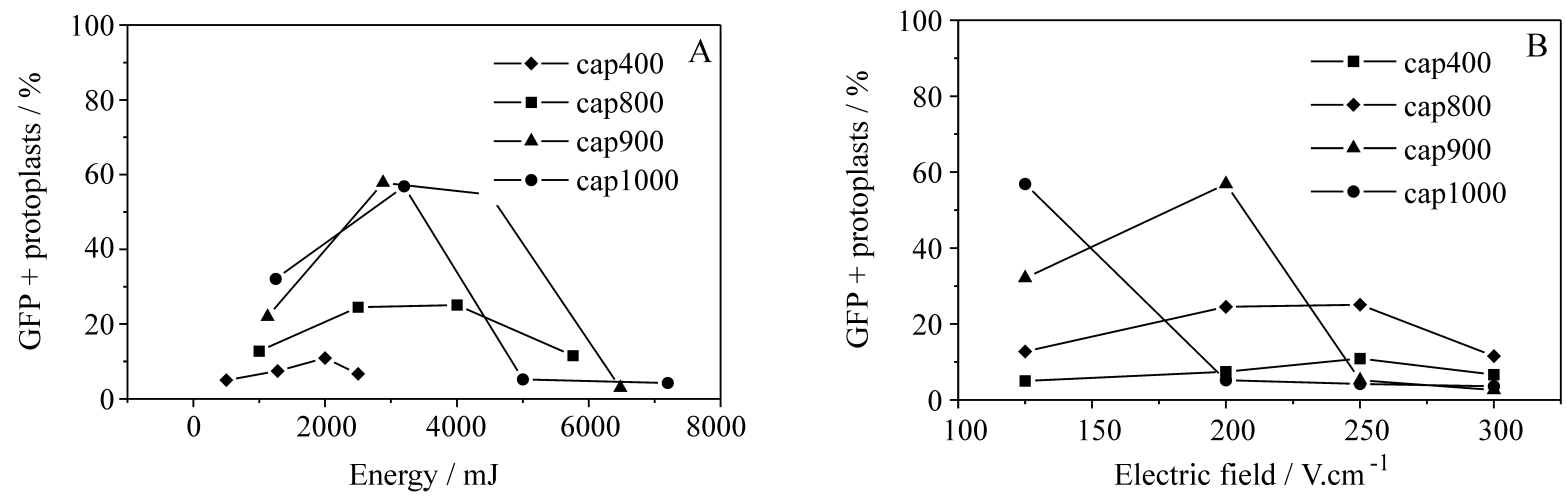

Figure 3 - GFP expression in $S$. guianensis protoplasts electroporated with different electric forces. (A) energy input (mJ) and (B) electric field strength $\left(\mathrm{V} . \mathrm{cm}^{-1}\right)$. Electroporation conditions were: $500 \mu \mathrm{F}, 20 \Omega$, buffer I, $10 \mu \mathrm{g}$ of supercoiled DNA. 


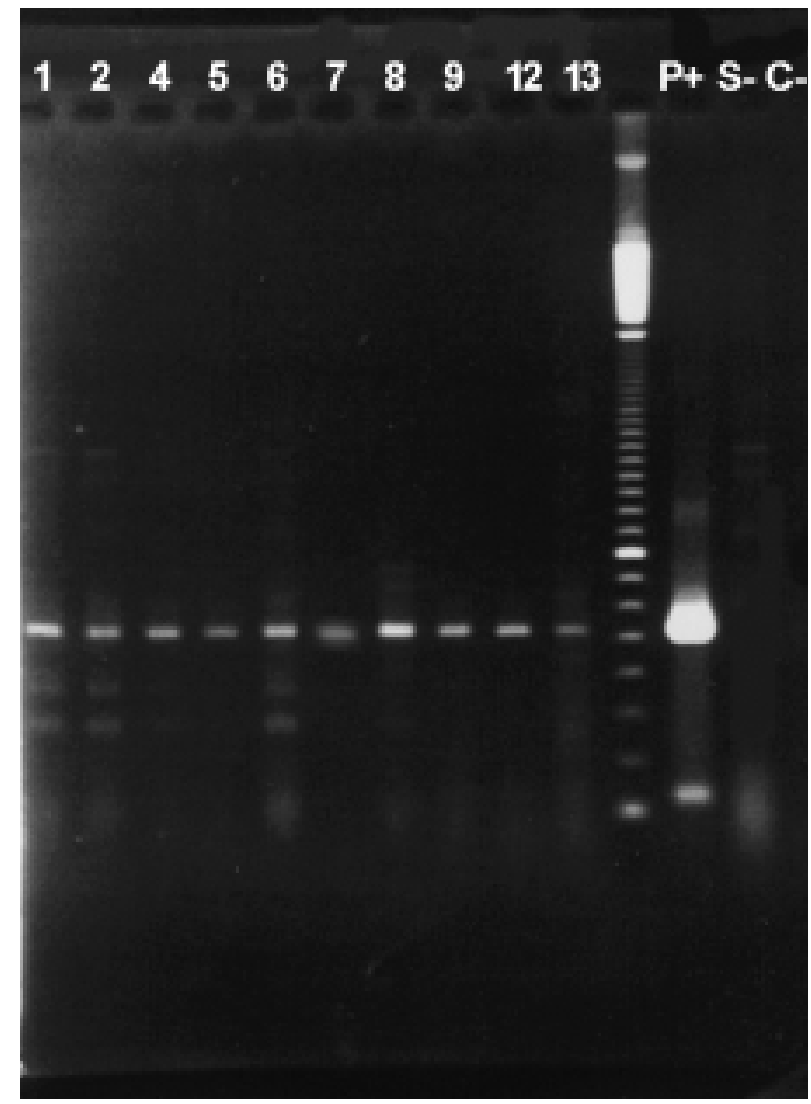

Figure 4 - Transgene PCR amplification in genomic DNA of S. guianensis regenerants derived from electroporated protoplasts. Regenerated plants are indicated as numbers on the lanes, $\mathbf{p}+=$ pCambia $1340, \mathbf{S}-=$ non-electroporated $S$. guianensis, $\mathbf{C}=$ without template DNA. Molecular weight maker $=100 \mathrm{bp}$ DNA ladder (GIBCO BRL).

transformation was lower than that expected from transient gene expression in electroporated protoplasts (Hain et al., 1985; Shillito et al., 1985), probably due to some retention of transgene expression ability in damaged protoplasts for periods shorter than $72 \mathrm{~h}$. The chloride ions in buffer I resulted in the production of toxic chlorine gas when electric pulses were applied, leading to a reduction in cellular viability (Figure 6B). In contrast to the data reported by Senaratna et al. (1991), we found that non-electroporated protoplasts incubated with plasmid DNA under the same

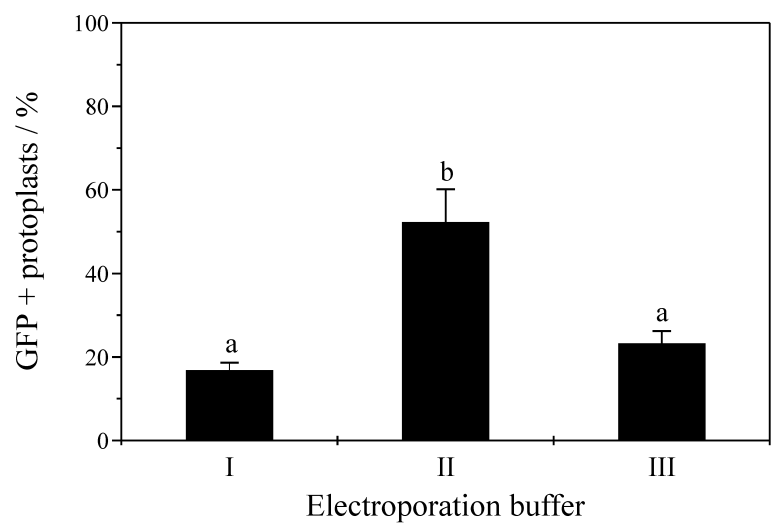

Figure 5 - GFP expression in electroporated $S$. guianensis protoplasts in buffer I (Fromm et al., 1987), buffer II (Tada et al., 1990) and buffer III (Wlalbot, 1993). Electroporation conditions were: $500 \mu \mathrm{F}, 100$ V.cm ${ }^{-1}, 20$ $\Omega$ for buffer I and III, $50 \Omega$ for buffer II, $10 \mu \mathrm{g}$ of supercoiled DNA. Bars indicate standard errors and small letters indicate significant differences at $\mathrm{p}<0.05$.

conditions for longer periods of time never showed transient expression of the reporter gene (Figure 6C).

In exponential wave electric circuits, the voltage decays exponentially in the electroporation buffer between the electrodes and the induced energy is dependent on the initially applied voltage and the charge accumulation capacity of the capacitor (Neumann et al., 1982, 1996). In this kind of circuit, the time constant $(\tau)$ is a function of the electrical resistance $(R)$ and the capacitance $(C)$ of the circuit according to the equation $\tau=\mathrm{RC}$, so that for a given capacitor $(\mathrm{C}=$ constant $)$ electroporation buffers with reduced ionic force impose less resistance to the movement of charge through the circuit and pulse decay time is longer. Kinosita and Tsong (1977) have demonstrated that longer duration pulses promote greater membrane permeability due to pore enlargement, and this probably contributed to the higher transformation rates which we observed with the low ionic force buffers II and III (Figure 5).

\section{Influence of DNA form on reporter gene expression}

Figure 7 shows that linear DNA was more efficiently introduced into electroporated protoplasts. Higher
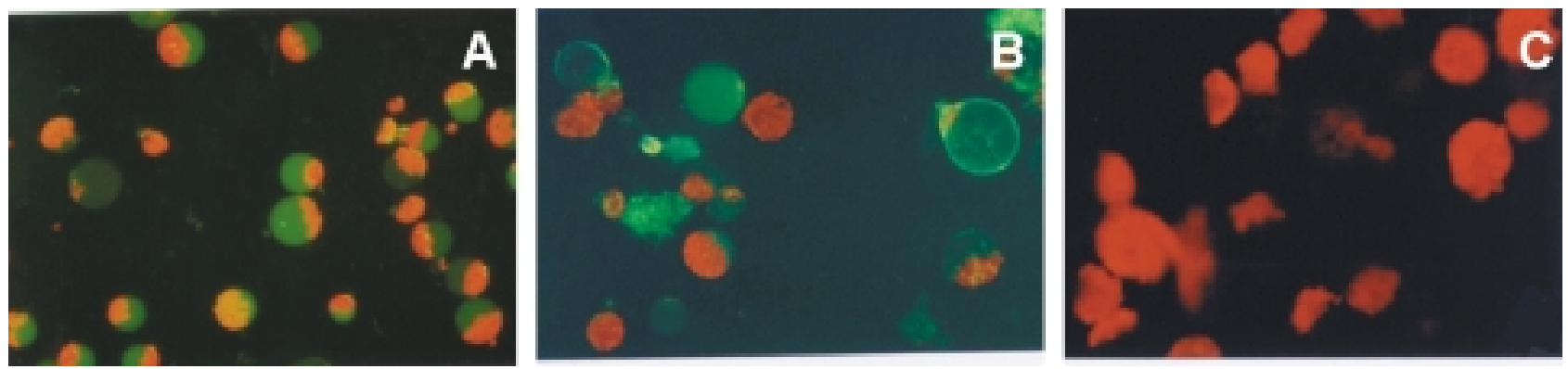

Figure 6 - GFP expression in S. guianensis protoplasts electroporated in (A) buffer II, (B) buffer I, (C) non-electroporated but incubated with plasmid DNA $(400 \mathrm{x})$. 


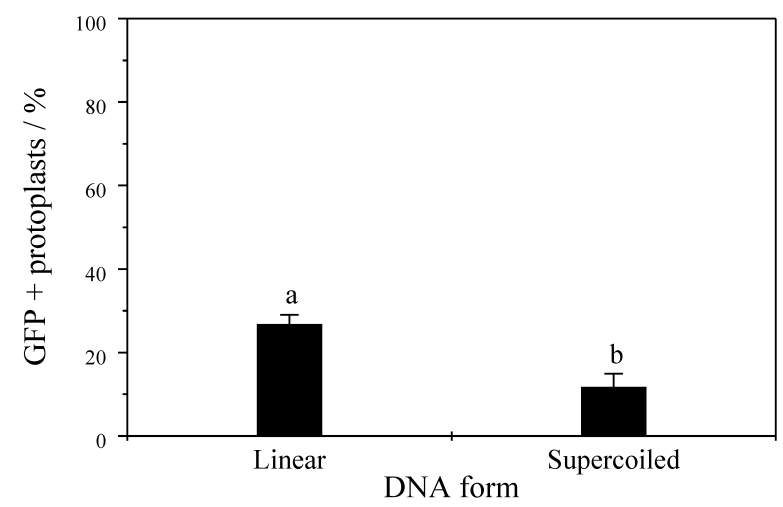

Figure 7 - GFP expression in S. guianensis protoplasts electroporated with supercoiled and linear plasmid DNA. Electroporation conditions were: $500 \mu \mathrm{F}, 20 \Omega$, buffer I, $10 \mu \mathrm{g}$ of supercoiled DNA. Bars indicate standard errors and small letters indicate significant differences at $\mathrm{p}<0.05$.

transformation efficiency using linear plasmid DNA has been reported for bacteria (Rittich and Spanova, 1996), yeasts and filamentous fungi (Kwon-Chung et al., 1998), plant protoplasts (Lin et al., 1997) and intact tissue (Akella and Lurquin, 1993; Dillen et al., 1995; Lin et al., 1997; Sabri et al., 1996; Saunders et al., 1995). Due to the inner twist of the molecule and to the absence of distortions imposed on the double helix structure (Drew et al., 1988), linear plasmid DNA is highly mobile under electric fields (Courey and Wang, 1983). Macromolecular movement across pores is facilitated when the molecules are linear because the absence of tertiary and quaternary structures reduces their volume (Tanaka, 1988) and allows a more uniform superficial polarization to be induced by the electric field (Neumann et al., 1982). The transient nature of membrane pores and of structural alterations to the cell wall induced by such electric fields imposes conformational restrictions on the type of macromolecules that can be introduced (Neumann et al., 1982).

Nandadeva et al. (1999) reported that the physical structure of DNA is critical for efficient transformation, with denatured molecules being much more favorable for transformation, although high transformation efficiency has been obtained with supercoiled plasmid DNA (Bates et al., 1990; Fromm et al., 1985; Oard et al., 1989).

In summary, we found that the critical factors regarding transgene expression in electroporated Stylosanthes guianensis protoplasts were energy input and electric field strength. A field strength of $250 \mathrm{~V} \cdot \mathrm{cm}^{-1}$ discharged by 900 and $1000 \mu \mathrm{F}$ capacitors gave the highest transient transformation frequencies. Linear plasmid DNA, absence of chloride and the presence of calcium ions also increased transient gene expression, although not significantly. Our data suggest that putative transgenic plants of $S$. guianensis can be obtained at high frequencies from electroporated protoplasts, on condition that an effective plant regeneration protocol is used.

\section{Acknowledgments}

We thank Dr. C. Karia (Embrapa/Cerrados) for kindly providing the Stylosanthes guianensis seeds. This research was supported by the Brazilian agency Fundação de Amparo à Pesquisa do Estado de São Paulo (FAPESP) Grant $\mathrm{N}^{\circ} .98 / 11270-7$. VMQ was the recipient of a Doctoral fellowship (Grant No. 141294/97-3) from the Brazilian agency Conselho Nacional de Desenvolvimento Científico e Tecnológico ( $\mathrm{CNPq})$.

\section{References}

Akella V, and Lurquin PF (1993) Expression in cowpea seedlings of chimeric transgenes after electroporation into seed-derived embryos. Plant Cell Rep. 12:110-117.

Ankenbauer RG and Nester EW (1993) The Agrobacterium Ti plasmid and crown gall tumorigenesis: A model for signal transduction in host-pathogen interactions. In: Nester ER (ed) Signal transduction: prokaryotic and simple eukaryotic systems. Academic Press Inc., New York, pp. 67-104.

Aragão FJL, Barros LMG, de Souza MV, Grossi de Sá MF, Almeida ERP, Gander ES and Rech EL (1999) Expression of a methionine-rich storage albumin from the Brazil nut (Bertholletia excelsa H.B.K., Lecythidaceae) in transgenic bean plants (Phaseolus vulgaris L., Fabaceae). Genet. Mol. Biol. 22:445-449.

Bates GW, Carle SA and Piastuch WC (1990) Linear DNA introduced into carrot protoplasts by electroporation undergoes ligation and recircularization. Plant Mol. Biol. 14:899-908.

Chalfie M, Tu Y, Euskirchen G, Ward WW and Prasher DC (1994) Green fluorescent protein as a marker for gene expression. Science 263:802-805.

Chand PK, Ochatt SJ, Rech EL, Power JB and Davey MR (1988) Electroporation stimulates plant regeneration from protoplasts of the woody medicinal species Solanum dulcamara L. J. Exp. Bot. 39:1267-1274.

Colby SM and Meredith CP (1990) Kanamycin sensitivity of cultured tissues of Vitis sp. Plant Cell Rep. 9:237-240.

Cônsoli L, Gaziola SA and Vieira MLC (1995) Plant transformation mediated by Agrobacterium rhizogenes: Optimization of the infection process. Braz. J. Genet. 18:115-119.

Cônsoli L, Vieira MLC, de Souza Jr. CL and Garcia AAF (1996) Tissue culture effects on quantitative traits in Stylosanthes guianensis (Leguminosae). Braz. J. Genet. 19:469-474.

Courey AJ and Wang JC (1983) Cruciform formation in a negatively supercoiled DNA may be kinetically forbidden under physiological conditions. Cell 33:817-829.

Dillen W, Engler G, van Montagu M. and Angenon G (1995) Electroporation-mediated DNA delivery to seedling tissues of Phaseolus vulgaris L. (common bean). Plant Cell Rep. 15:119-124

Dornelas MC, Vieira MLC and Appezzato-da-Glória B (1992) Histological analysis of organogenesis and somatic embryogenesis induced in immature tissues of Stylosanthes scabra. Ann. Bot. 70:477-482.

Dornelas MC, Vieira MLC and Souza Jr. CL de (1991) Fonte e idade de explante, radiação luminosa e combinações de NAA e BAP na indução de calos em Stylosanthes scabra Vog. Pesq. Agropec. Bras. 26:1901-1909. 
Dower WJ, Miller JF and Ragsdale CW (1988) High efficiency transformation of $E$. coli by high voltage electroporation. Nucleic Acid Res. 16:6127-6145.

Drew HR, McCall MJ and Calladine CR (1988) Recent studies of DNA in the crystal. Ann. Rev. Cell. Biol 4:1-20.

Edwards K, Johnstone C and Thompson C (1991) A simple and rapid method for the preparation of plant genomic DNA for PCR analysis. Nucleic Acid Res. 19:1349.

Fromm M, Callis J, Taylor LP and Walbot V (1987) Electroporation of DNA and RNA into plant protoplasts. Methods Enzymol. 153:351-365.

Fromm ME, Taylor LP and Walbot V (1985) Expression of genes transferred into monocot and dicot plant cells by electroporation. Proc. Natl. Acad. Sci. USA 82:5824-5828.

Gilmour DM, Davey MR and Cocking EC (1989) Production of somatic hybrid tissues following chemical and electrical fusion of protoplast from albino cell suspensions of Medicago sativa and M. borealis. Plant Cell Rep. 8:29-32.

Hain R, Stabel P, Czernilofsky AP, Steibib HH, Herrera-Estrella $\mathrm{L}$, and Schell J (1985) Uptake, integration, expression and genetic transmission of a selectable chimaeric gene by plant protoplasts. Mol. Gen. Genet. 199:161-168.

Hanahan D (1983) Studies on the transformation of Escherichia coli with plasmids. J. Mol. Biol. 166:557-580.

Hauptmann RM, Ozias-Akin P, Vasil V, Tabaeizaden Z, Rogers SG, Horsch RB, Vasil IK and Fralwy RT (1987) Transient expression of electroporated DNA in monocotyledonous and dicotyledonous species. Plant Cell Rep. 6:265-270.

Hoffmann LV (1998) Regeneração de plantas e expressão transiente de GUS em Stylosanthes guianensis (Aubl.) Sw. via Agrobacterium. M.Sc. Thesis, Escola Superior de Agricultura "Luiz de Queiroz", Universidade de São Paulo, Piracicaba, São Paulo.

Jefferson RA, Kavanagh TA and Bevan MW (1987) GUS fusion : the $\beta$-glucuronidase as sensitive and versatile gene fusion marker in higher plants. EMBO J. 6:3301-3307.

Kao N (1977) Chromosomal behavior of somatic hybrids of soybean x Nicotiana glauca. Mol. Gen. Genet. 150:225-230.

Kinosita K and Tsong TY (1977) Voltage-induced pore formation and hemolysis of human erythrocytes. Biochem. Biophys. Acta 471:227-242.

Kwon-Chung KJ, Goldman WE, Klein B, Szaniszla PJ, Polonelli LO and Walsh TJ (1998) Fate of transforming DNA in pathogenic fungi. Med. Mycol. 36:38-44.

Langridge WHR, Li BJ and Szalay AA (1987) Uptake of DNA and RNA into cells mediated by electroporation. Methods Enzymol. 153:336-350.

Lin CH, Xiao L and Hou BH (1997) Optimization of electroporation conditions for expression of GUS activity in electroporated protoplasts and intact cells. Plant Physiol. Biochem. 35:959-968.

Liu CJ, Musial JM and Smith FW (1996) Evidence for a low level of genomic specificity of sequence-tagged sites in Stylosanthes. Theor. Appl. Genet. 93:864-868.

Lovato MB and Martins PS (1997) Genetic variability in salt tolerance during germination of Stylosanthes humilis H.B.K. and association between salt tolerance and isozymes. Braz. J. Genet. 20:435-441.

Manner JM (1987) Transformation of Stylosanthes spp. using Agrobacterium tumefaciens. Plant Cell Rep. 6:204-207.
Manners JM and Way H (1989) Efficient transformation with regeneration of tropical pasture legume Stylosanthes humilis using Agrobacterium rhizogenes and a Ti plasmid binary vector system. Plant Cell Rep. 8:341-345.

Manners JM (1988) Transgenic plants of the tropical pasture legume Stylosanthes humilis. Plant Sci. 55:61-68.

Mauro AO, Nóbrega JC, Baraldi GL and Collins GB (1995) Susceptibility of some Brazilian soybean genotypes to three strains of Agrobacterium tumefaciens. Braz. J. Genet. 18:417-420

McCabe DE, Swain WF, Matinell JB and Christou P (1988) Stable transformation of soybean (Glicine max) by particle acceleration. Bio/Tech. 6:923-926.

Meijer EGM and Szabados L (1990) Cell and tissue culture of Stylosanthes spp. In: Biotechnology in agriculture and forestry. Legumes and oilseed crops. (Bajaj, Y.P.S., ed.). Springer Verlag, Heidelberg, pp.312-322.

Murashige T. and Skoog F (1962) A revised medium for rapid growth and bioassays with tobacco tissue cultures. Physiol. Plant. 15:473-497.

Nandadeva YL, Lupi CG, Meyer CS, Devi PS, Potrykus I and Bilang R (1999) Microprojectile-mediated transient and integrative transformation of rice embryogenic suspension cells: effects of osmotic cell conditioning and of the physical configuration of plasmid DNA. Plant Cell Rep. 18:500-504.

Neumann E, Kakorin S and Tsoneva I (1996) Calcium-mediated DNA adsorption to yeast cells and kinetics of cell transformation by electroporation. Biophys. J. 71:868-877.

Neumann E, Schäefer-Ridder M, Wang M and Hofschneider PH (1982) Gene transfer into mouse lyoma cells by electroporation in high electric fields. EMBO J. 1:841-845.

Oard JH, Paige DF, Simmonds JA and Gradziel TM (1989) Transient gene expression in maize, rice and wheat cells using an airgun apparatus. Plant Physiol. 92:334-339.

Ochatt SJ, Chand PK, Rech EL, Davey MR and Power JB (1988) Electroporation-mediated improvement of plant regeneration from colt cherry (Prunus avium $\mathrm{x}$ pseudocerasus) protoplasts. Plant Sci. 54:165-169.

Partridge I (1996) Protecting stylos from anthracnose. Rural Res. 171:29-32.

Potrykus I (1990) Gene transfer to plants: assessment and perspectives. Physiol. Plant. 79:125-134.

Potrykus I (1991) Gene transfer to plants: assessment of published approaches and results. Ann. Rev. Plant Physiol. Plant Mol. Biol. 42:205-225.

Quecini VM (1999) Transferência direta de genes para plantas de Stylosanthes guianensis (Aubl.) Sw. Ph.D. Thesis, Escola Superior de Agricultura "Luiz de Queiroz", Universidade de São Paulo, Piracicaba, São Paulo.

Quoirin M, Aragão F, Rech E and de Oliveira DE (1997) Transient expression of a reporter gene introduced by bioballistic bombardment into Racosperma mangium (Leguminosae family) tissues. Braz. J. Genet. 20:507-510.

Rech EL, Ochatt SJ, Chand PK, Davey MR, Mulligan BJ and Power JB (1988) Electroporation increases DNA synthesis in cultured plant protoplasts. Bio/Tech. 6:1091-1093.

Rech EL, Ochatt SJ, Chand PK, Power JB and Davey MR (1987) Electro-enhancement of division of plant protoplast-derived cells. Protoplasma 141:169-176.

Rittich B. and Spanova A. (1996) Electrotransformation of bacteria by plasmid DNAs: statistical evaluation of a model quan- 
titatively describing the relationship between the number of electrotransformants and DNA concentration. Bioelectroch. Bioener. 40:233-238.

Sabri N, Pelissier B and Teissie J (1996) Transient and stable electrotransformation of intact black Mexican sweet maize cells are obtained after preplasmolysis. Plant Cell Rep. 15:924-928.

Sambrook J, Fritsch EF and Maniatis T (1989) Molecular cloning: a laboratory manual. Cold Spring Harbor Laboratory Press, New York.

Sarria R, Calderón A, Thro AM, Torres E, Mayer JE and Roca WM (1994) Agrobacterium-mediated transformation of Stylosanthes guianensis and production of transgenic plants. Plant Sci. 96:119-127.

Saunders JA, Lin CH and Hou BH (1995) Rapid optimization of electroporation conditions for plant cells, protoplasts and pollen. Mol. Biotechnol. 3:181-190.

Senaratna T, Mckersie BD, Kasha KJ and Procunier JD (1991) Direct DNA uptake during the imbibition of cells. Plant Sci. 79:223-228.

Shillito RD, Saul MW, Paszkowski J, Müller M and Potrykus I (1985) High efficiency direct gene transfer to plants. Bio/Tech. 3:1099-1103.
Tada Y, Sakamoto M and Fujimura T (1990) Efficient gene introduction into rice by electroporation and analysis of transgenic plants: use of electroporation buffer lacking chloride ions. Theor. Appl. Genet. 80:475-480.

Tanaka T (1988) Gels. Sci. Amer. 244:124-138.

Valarini MJ, Otsuk IP and Vieira MLC (1997) Changes in $\mathrm{N}_{2}$ fixation in Stylosanthes scabra derived from tissue culture. Braz. J. Genet. 20:713-716.

van der Stappen J, van Campenhout S, and Lopez SG (1998) Sequencing of the internal transcribed region ITS1 as a molecular tool detecting variation in the Stylosanthes species complex. Theor. Appl. Genet. 96:869-877.

Vieira MLC, Fungaro MHP, Jubier MF and Lejeune B (1997) Determination of taxonomic relationship among Brazilian taxa of Stylosanthes SW., Leguminosae, using RAPD markers. Pesq. Agrop. Bras. 3:305-310.

Vieira MLC, Jones B, Cocking EC and Davey MR (1990) Plant regeneration from protoplasts isolated from seedling cotyledons of Stylosanthes guianensis, S. macrocephala and $S$. scabra. Plant Cell Rep. 9:289-292.

Walbot V. (1993) Gene pulser electroprotocols, survey number 181, Bio-Rad Laboratories, Hercules-CA.

Yang NS (1993) In: Transgenic plants Kung SD and Wu R (eds) Transgenic plants from legumes. Academic Press, San Diego, pp.79-102. 